\title{
Autor i kulisy - przypadek Pawła Demirskiego
}

\author{
Paweł Stangret
}




\section{Autor i kulisy - przypadek Pawła Demirskiego}

Paweł Stangret

TEKSTY DRUGIE 2017, NR 4, S. 253-272

DOI: 10.18318/td.2017.4.16
Artykułjest wynikiem badań finansowanych przez NCN w ramach projektu Artysta jako tekst. Konstrukt tożsamościowy reżysera jako komentarz do działań teatralnych. Główne tezy artykułu były prezentowane na konferencjach "Szybkość w kulturze" (20-21 maja 2015, UKSW) oraz „Rozpoznane. Przedstawione. Nazwane. Świat (w) polskiej dramaturgii najnowszej" (27-28 maja 2015, UKSW, IBL).

Paweł Stangret adiunkt w Katedrze Badań nad Teatrem i Filmem UKSW. Autor książki Tadeusz Kantor pisarz. Badania koncentruje na zagadnieniu tekstowości w sztuce nowoczesnej - zwłaszcza na pograniczu sztuk wizualnych (głównie teatru) i literatury. Obecnie realizuje w NCN projekt badawczy Artysta jako tekst poświęcony dyskursom tożsamościowym artystów teatru (Kantora, Lupy, Strzępki i Demirskiego). Kontakt: ps.stangret@gmail.com 
Teatr Miejski nawiązuje do Szybkiej Kolei Miejskiej - podstawy komunikacji w Trójmieście. Projekt bowiem wpisuje się w sposób funkcjonowania Teatru Wybrzeże, który pod ówczesnym zarządem łączył nowoczesną estetykę sceniczną z działalnością pozateatralną, którą można określić jako społeczno-edukacyjną. W jej ramach, w teatrze, prowadzono dyskusje na tematy polityczne - spotkania pomyślane jako dynamiczne, wzbudzające kontrowersje - zapraszano bowiem osoby prezentujące odmienne stanowiska.

W omawianym okresie działał także Wybrzeżak - założona w 1995 roku Sekcja Edukacyjna teatru. Te inicjatywy nie tylko były kojarzone z teatrem, lecz również cieszyły się dużą frekwencją i spełniały swoją funkcję wspólnototwórczą, organizując publiczność wokół Teatru Wybrzeże. Warto zaznaczyć, że przy takim zapleczu i z taką świadomością, jaką funkcję pełni gdańska scena, zorganizowano w teatrze transmisję z mszy pogrzebowej Jana Pawła II, myśląc właśnie o kreowaniu społeczności wokół teatru. To także się udało, $\mathrm{w}$ wielu wypowiedziach zapisanych w notkach prasowych uczestnicy transmisji mówili o wspólnocie generowanej przez widowisko. Do tego dochodzi słynna akcja sprzedaży biletów za złotówkę dla bezrobotnych (na podstawie aktualnego zaświadczenia z Urzędu Pracy i dowodu osobistego).

Bardzo istotne jest także poszerzanie swojej publiczności. Zarówno Demirski, jak i Nowak celowo dostosowywali koncepcję nowoczesnego teatru do nowej publiczności. Rzecznik Teatru Wybrzeże tak skomentował akcję bilety za złotówkę. „Szukamy nowej widowni, która nie zalicza się do teatromanów, ani do elity”. Chodziło o to, aby teatr poruszał, jak to określił „społeczne problemy normalnych ludzi dla normalnych ludzi"1. Chodziło więc nie tylko o zmianę estetyczną, ale o nowe miejsce teatru w społeczeństwie.

Dużo mocniej wypowiedział się dyrektor Maciej Nowak: „Nie chcemy być azylem dla grupy mądrali i kulturalnych ciotek, przekonanych o swojej wyjątkowości. Tzw. polska inteligencja zajęła się ciągłym narzekaniem, które usprawiedliwia pasywność intelektualną i konsumpcyjny apetyt. Nasz teatr nie ma z tą publicznością wspólnych tematów"2. Projekt Demirskiego miał więc $z$ jednej strony zadania społeczno-edukacyjne. $Z$ drugiej zaś był przełomem estetycznym, zapoczątkował modę na teatr narracji w Polsce, czego Demirski był świadomy. Szybki Teatr Miejski stał się jego swoistym mitem założycielskim - zarówno jeśli chodzi o kondycję artysty zaangażowanego, jak i pod względem sukcesu. Odbija się tutaj charakterystyczna dla twórczości

1 "Nowiny. Gazeta Codzienna", Rzeszów 23.12.2004 nr 250.

2 "Dziennik Bałtycki. Wieczór Wybrzeża”, Gdańsk 2.03.2005 nr 51. 
awangardowej dychotomia między chęcią masowości a wysublimowanym estetycznie projektem.

W tak ukształtowanej przestrzeni komunikacyjnej Paweł Demirski inicjuje swoją działalność. W ramach projektu powstało sześć przedstawień: w 2004 roku zaprezentowane zostało Padnij. Żony polskich żołnierzy w Iraku z tekstem Pawła Demirskiego i Andrzeja Mańkowskiego, w reżyserii Piotra Waligórskiego, Nasi (Neonaziści) z tekstem Joanny Sztukator i Anny Trojanowskiej, w reżyserii Anny Trojanowskiej, Przebitka (gra aborcyjna) z tekstem Izabelli Wąsińskiej, w reżyserii Agnieszki Olsten oraz Kobiety zza wschodniej... z tekstem i w reżyserii Magdaleny Vegi Ostrokólskiej i Marcina Koszałki. W następnym roku pokazano Pamiętnik z dekady bezdomności Anny Łojewskiej w adaptacji Pawła Demirskiego, w reżyserii Romualda Wiczy-Pokojskiego, zaś w 2006 roku premierę miał Kiedy przyjda podpalić dom, to się nie zdziw Pawła Demirskiego w reżyserii Romualda Wiczy-Pokojskiego. Spektakl powstał na podstawie dramatu, jednakże poprzedzony był kwerendą terenową prowadzoną przez autora w Łodzi.

Główną zasadą projektu była aktualność społeczna, szybkość przepływu informacji. W wersji Demirskiego powinna być ona skuteczna. Jednakże skuteczność rozumiana jest tutaj nie jako kategoria perswazji. Założeniem Szybkiego Teatru Miejskiego było pokazanie problemu, zwrócenie na niego uwagi oraz chęć poznania danego zjawiska. Istotą była więc chęć informowania odbiorcy o problemie i zaserwowania mu materiału informacyjnego. Sam Demirski tak powie o swoim przedsięwzięciu:

Jest jeden ważny powód robienia takiego teatru. Chodzi o to, by nie tworzyć fikcji społecznej. Jeśli chcemy o jakimś problemie mówić, musimy go poznać. Trzeba rozmawiać z ludźmi, aby nie zakłamywać świata. Oczywiście, nie jest to czysty zapis dialogu. Odtwarzamy kontekst, w jakim żyją bohaterowie, tworzymy napięcia, które coś znaczą, a które niekoniecznie są w materiale. Ważna jest też pointa. Chodzi o to, aby widz wyrobił sobie jakiś pogląd, miał własne zdanie na ważne społeczne problemy. ${ }^{3}$

Demirski wielokrotnie podkreślał (i wówczas, i w wypowiedziach z późniejszego okresu, a także w metaliterackich fragmentach swoich dramatów), że nie wierzy w skuteczność perswazji estetycznej (na pewno w odniesieniu do medium teatralnego). W jednej z wypowiedzi à propos Szybkiego Teatru

3 P. Demirski, „Kulisy” 26.03. 2004 nr 12. 
Miejskiego zarzuca publiczności, że Padnij! odbierane jest w kategoriach estetycznych. Dopiero po publikacjach medialnych dotyczących przymuszania ochotników oraz pokazujących motywacje finansowe polskich żołnierzy i ich rodzin, publiczność zaczęła odbierać spektakl jako komunikat interwencyjny, jako element dyskursu społecznego, wykraczającego poza jakości sztuki.

W przypadku tego typu twórczości istotna jest kwestia aktualności poruszanych tematów. Teatr ten wyrasta z problemów istotnych dla publiczności. Oczywiście, Szybki Teatr Miejski nawiązuje do tradycji „gazetowości” Erwina Piscatora, czy idei Zeittheather Leona Schillera ${ }^{4}$. Istotna jest jednak modyfikacja prowadzona przez Demirskiego. Teatr polityczny z założenia powinien być perswazyjny, autor nie może ukrywać zarówno swoich poglądów, jak też swojej perspektywy komunikacyjnej. Demirski nie chce agitować, chce informować, oczywiście jednocześnie podkreślając silną perspektywę autorską, która miała być według niego polską modyfikacją verbatimu.

To autorskie, estetyczne przetworzenie było powodem krytyki ${ }^{5}$. W negatywnych recenzjach właśnie arbitralne "narzucenie” tematu traktowano jako "robienie" problemu, mówiąc językiem mediów - kreacji newsa, na stwarzaniu pozoru aktualności, gorącości, a także szybkości przekazu. Zarzut ten jest o tyle istotny, że praca nad spektaklami (a o kulisach metody artystycznej zarówno Demirski, jak i Nowak mówili wiele) była elementem spowalniającym, dalekim od postulatu szybkiej informacji. Co więcej, było to spowalnianie w kilku aspektach. Po pierwsze, zbieranie materiałów, dokumentacja - to ważne słowo pokazujące ruch przeciwny szybkości. Praca terenowa była dla projektu bardzo ważna i prowadzona drobiazgowo. Na przykład materiał do Padnij! zbierano w Zielonym Garnizonie na Śląsku, powstał więc w wyniku reporterskiej kwerendy. Kolejnym spowolnieniem jest dramaturgiczne przetworzenie zebranego materiału na język przedstawienia. Co więcej, język nowy, nowej konwencji estetycznej. Trzecim zaś elementem spowolnienia jest cel takiego postępowania. Odejście Demirskiego od perswazji na rzecz informacji ma także swoje konsekwencje w kontekście szybkości, zarzut Małgorzaty Jarmułowicz pokazuje, że właśnie szybkość poruszanej problematyki jest konwencją estetyki proponowanej przez STM-kę.

Problemem i jednocześnie zarzutem kierowanym pod adresem tej koncepcji jest właśnie kwestia informowania. Twórcy prowokują nie tylko dzięki pokazaniu problemu, przypomnieniu o nim, ale także dzięki informacjom

4 R. Pawłowski Zeittheater. Reaktywacja, "Notatnik Teatralny” $2011 \mathrm{nr}$ 64-65.

5 M. Jarmułowicz Verbatim nad Mołtawq , "Dialog” 2004 nr 7. 
o nim. Demirski wielokrotnie podkreśla konieczność „zrozumienia”, nabycia wiedzy o zjawisku. Newsowość Szybkiego Teatru Miejskiego akcentuje bowiem problem podnoszony przez badaczy nowych mediów, polegający na nowym sposobie nabywania wiedzy, kiedy to informacja staje się wiedzą ${ }^{6}$. Właśnie taki sposób komunikacji zarzucają twórcom krytycy ${ }^{7}$. Według dramaturga spektakl ma być materiałem do wyrobienia sobie zdania na temat wypierany w dyskursie społecznym. Jednakże często podkreślano w krytycznych komentarzach, że te przedstawienia pozbawione są bogatej warstwy informacyjnej.

Spektakle poświęcone były kontrowersyjnym problemom życia społecznego. Prowokacja polegała przede wszystkim na diagnozie wyrażonej w postaci silnej tezy definiującej wyparte zjawisko. Polscy żołnierze przebywający z misją w Iraku pojechali tam zarabiać pieniądze, przy czym nie zawsze wyjazd ten był dobrowolny. Neonaziści z Gdańska, którzy zeszli już z pierwszych stron gazet, istnieją nadal i prowadzą działalność w ukryciu, podziemie aborcyjne istnieje, a przerwanie ciąży nie jest kwestią moralną, lecz głównym problemem jest penalizacja i to, aby nie dać się złapać. Losem emigrantów ze Wschodu, którzy związani są z Polską jedynie ekonomicznie, a tęsknią za ojczyzną, nie przejmujemy się, podobnie jak usuwamy z pola świadomości problematykę bezdomności. Do tego stworzyliśmy system społeczny, w którym jednostka - pracownik ma niewspółmiernie małą pozycję w starciu z państwowo-biznesowymi instytucjami. Tak można streścić zawartość „informacyjną” tych spektakli.

Zmianą, jakie nowe media wprowadzają, jest skrócenie relacji informacji i wiedzy. Lektura linearna stawia odbiorcę przed perspektywą przebycia drogi informacja - analiza/interpretacja - wiedza. Nowe media (paradoksalnie, bo dają dużo większe możliwości do gromadzenia materiału do analizy - porównań, odwołań etc.) skracają tę drogę, prowadząc do sytuacji, w której to sama informacja staje się wiedzą ${ }^{8}$. Takie zarzuty padają pod adresem Szybkiego Teatru Miejskiego. Pisano, że jest to projekt, po którym widz wychodzi ze złudnym przeświadczeniem, że zdobył pewną wiedzę na omawiany temat.

6 Por. N.C. Burbules Retoryka sieci: hiperlektura oraz krytyczny poziom piśmienności, przeł. .. Mach, w: Ekrany piśmienności, red. A. Gwóźdź, Wydawnictwa Akademickie i Profesjonalne, Warszawa 2008.

7 M. Jarmułowicz Verbatim nad Mołtawą.

8 N.C. Burbules Retoryka sieci: hiperlektura oraz krytyczny poziom piśmienności.

9 M. Jarmułowicz Verbatim nad Mołtawą. 
Jest to kolejny, ważny aspekt szybkości zawartej w nazwie projektu. Tak podany materiał informacyjny ma być wiedzą, jaką widz wynosi ze spektaklu. Oczywiście krytycy zarzucają, nieuniknioną w takim sposobie komunikacji, banalizację problematyki. O Kobietach zza wschodniej, że jest to spektakl nic niewnoszący do wiedzy na temat emigrantek z Ukrainy, pisze Katarzyna

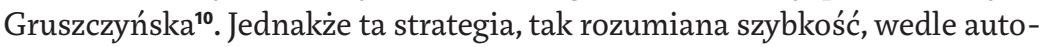
rów polegała na tym, że właśnie szybko otrzymana porcja materiału ma być punktem wyjścia do „wolnej” analizy i spokojnego, indywidualnego procesu dochodzenia do wiedzy.

Istotnym aspektem związanym z szybkością jest kontrowersyjność poruszanych problemów. Prowokacja polega na wynajdywaniu problemu przemilczanego, odsuwanego. Dzięki rozbijaniu dyskursu społecznego, akcentowaniu elementu w nim nieobecnego, tematyka zyskuje znamiona szybkości - na poziomie emocjonalnym. Tak pokazane zjawisko wydaje się problemem do natychmiastowego rozwiązania, a na pewno służącym do zmotywowania odbiorcy, aby zajął stanowisko wobec niego. Maciej Nowak po pierwszych odsłonach powiedział: „To nie jest tak, że artyści wymyślają niemoralne tematy. [...] Musimy mieć świadomość, że to się wokół nas dzieje"11. Właśnie takie zaangażowanie artysty jest bezpośrednio powiązane z kategorią funkcjonalną. Sama szybkość takiego teatru ma swoją siłę perswazyjną, jest skutecznym narzędziem debaty kulturowej - łączy bowiem twórcę z komunikatem. Pokazuje nie tylko, że autor potrafi szybko zdefiniować problem, lecz oznacza również, że umie ocenić zjawiska pod kątem ich funkcjonalności w kulturze.

Aktualność, szybkość reakcji sztuki stanowi wyznacznik nowej estetyki, estetyki funkcjonalnej, która wykracza poza dzieło. Chodzi o to, „żeby widz mógł skonfrontować to, co wie, z tym, co się dzieje na scenie, żeby uważniej przyjrzał się rzeczywistości po wyjściu ze spektaklu, żeby odczarować ten niby znajomy świat"12. Koncepcja relacji pomiędzy sceną i widownią w tym przypadku polega na kreacji szybkości poprzez wytrącanie widza z bezpiecznego statusu wiedzy (i zastąpieniu wiedzy widza wiedzą nową), poprzez wzbudzenie refleksji nad sposobami społecznej komunikacji, sposobami mówienia o problemie. Widz w takiej sytuacji, w sytuacji pozbawienia go bezpieczeństwa, skonfrontowany jest z problemem, który nagle zyskuje na

K. Gruszczyńska, "Głos Wybrzeża” 17.03.2004 nr 53.

"Głos Wybrzeża" 3.11. 2004 nr 211.

12

Muzeum Hańby Narodowej. Rozmowa Pawła Demirskiego z Wojciechem Wojciechowskim , No-
tatnik Teatralny" 2007 nr 45/46. 
aktualności. Estetyczne przetworzenie realnego materiału uruchamia konstytutywne dla teatru, zaakcentowanie już w Poetyce Arystotelesa kategorie - sytuuje bowiem odbiorcę pomiędzy chęcią i doświadczeniem identyfikacji a poczuciem bezpieczeństwa, dystansu gwarantowanego przez fikcję. W tym przypadku to poczucie bezpieczeństwa jest cały czas podważane.

Właśnie dlatego Demirski decyduje się na specyficzną formę - spektakl, który przekracza granice swojej konwencji. W odsłonach Szybkiego Teatru Miejskiego głównym elementem był gdański autobus który odjeżdżał z siedemnastoma widzami. Bilety na projekt, ujęty w repertuarze Teatru Wybrzeże, kupowało się na autobus. Spektakle były grane w prywatnych mieszkaniach w różnych częściach Trójmiasta, a autobus woził widzów pomiędzy miejscami nieteatralnymi, „realnymi” - tak były nazywane przez twórców. Wyjątkiem była Przebitka grana na scenie teatralnej, jednak w odteatralizowanej konwencji - spektakl był wyreżyserowany jako kryminalna RPG. Urealnienie i próba zatarcia granic dzieła najmocniej była widoczna w Pamiętniku z dekady bezdomności, który grany był w Schronisku św. Brata Alberta w Gdańsku. W spektaklu statystowali również mieszkańcy noclegowni.

Właśnie ta forma, zbliżania teatru do realności, odteatralnienie go była kwintesencją tego projektu. Autobus kursujący pomiędzy spektaklami też miał być odwzorowaniem Szybkiej Kolei Miejskiej, podstawy komunikacji Trójmiasta. Paweł Demirski, odwołując się do kolei, powiedział: „Stworzyliśmy STM, bo chcieliśmy sprawnie poruszać się po mieście - wsiadać z publicznością do tych wagonów, które są, naszym zdaniem, interesujące"13. Wyprowadzenie teatru nie tylko w przestrzeń niesceniczną, ale w przestrzeń realną jest tutaj najbardziej kontrowersyjnym zabiegiem. Wspomniana już Małgorzata Jarmułowicz zarzuca projektowi Demirskiego, że tak rozumiana realność jest „tautologiczna”, sprawia, że sztuka staje się „znakiem ikonicz-

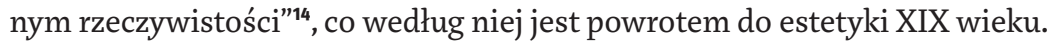
Ogólną ideę przyrównuje do zorganizowanych, profesjonalnych safari, które są namiastką, kopią. Oskarża Demirskiego, że fikcjonalną rzeczywistość komunikuje jako rzeczywistość. Podobnie Jacek Sieradzki, ironizując na temat czystego i niezatłoczonego autobusu, zarzuca Demirskiemu, że odteatralizowanie nie powiodło się, zaś w odniesieniu do spektakli „liczyły się

13 Nowe środki komunikacji, rozmowa Pawła Demirskiego i Adama Majewskiego, "Didaskalia” 2005, nr 6/-68, s. 111. 
kryteria konwencjonalnego teatru"15. Wartości estetyczne są dla niego z kolei bardzo pozytywne, ponieważ dalej napisał, że Szybli Teatr Miejski to „jedna z ciekawszych kreacji sezonu"16. Ważne, że autorzy spektakli podkreślali tę kreacyjność.

Teatr interwencyjny to dla Demirskiego kwintesencja szybkości. Mówiąc o przetworzeniu realnego materiału, zaznaczał, że istnieje potrzeba zbudowania relacji dramatycznych opartych na postaciach, ponieważ to rodzi „emocje”, napięcie między widownią i aktorami. Co więcej, "granie w mieszkaniu to świetna sytuacja. Reakcje widów są bardzo czytelne - słychać każde westchnienie"17 - stwierdziła Maria Mielnikow. Komunikacja teatralna jest szybka, oparta na bezpośredniej i bezpośrednio danej interakcji, interakcji zmaterializowanej ${ }^{18}$.

Szybkość teatru polega także na tym, że język tej sztuki musi być nieustannie i performatywnie uaktualniany do potrzeb realnych użytkowników. Demirski tak scharakteryzował estetykę swoich tekstów:

Nie wszyscy wiedzą, czym jest nowa dramaturgia. Nie jest to literatura, która powstała niedawno. A nowa jest dlatego, że bierze pod uwagę czas, w którym żyjemy, a także zmiany, jakie zaszły w percepcji widza. Nie chodzi o to, aby na scenie pojawił się telewizor, telefon komórkowy i internet, lecz o to, by pokazać, w jaki sposób zmienia nasze umysły powszechny dostęp do technologii. Panuje również błędne przekonanie, że współczesna rekwizytornia może odmłodzić klasyczne sztuki, które stają się chyba mniej pojemne? w obliczu zaistniałych na planecie zmian. $^{19}$

Demirski o niezrozumiałości struktury metaforyki teatralnej powie, że jest ona wynikiem dążenia środowiska teatralnego do bycia elitą ${ }^{20}$. Dramaturg łączy kwestie estetyczne, społeczno-ekonomiczne, polityczne oraz medialne

J. Sieradzki Doktrynalny gwizdek miejski, „Przekrój” 11.04. 2004 nr 15.

Tamże.

M. Mielnikow, "GW Trójmiasto” 15.11.2004 nr 267.

E. Fischer-Lichte Estetyka performatywności, przeł. M. Borowski, M. Sugiera, Księgarnia Akademicka, Kraków 2008.

Nowe środki komunikacji, s. 112.

Muzeum Hańby Narodowej, s. 74. 
w jednej wypowiedzi. Struktura jego komunikatu jest konwergentna ${ }^{21}$. Jest szybka - w jedną formę zdolna połączyć wiele różnych kodów. Oczywiście ukształtowana jest na wzór nowoczesnych mediów, dla których szybkość jest podstawą strukturalną. Dlatego właśnie Demirski zaznaczył, że podstawowym środkiem artystycznym w Szybkim Teatrze Miejskim jest montaż ${ }^{22}$. Szybkość nie jest więc tutaj teoretycznym założeniem, ale strukturalną koniecznością nie tyle komunikacji, ile istnienia w nowoczesnym dyskursie. Jacek Sieradzki, kończąc swój tekst, pisze, że spektakle gdańskiego projektu można by zagrać na scenie, ale „czy wówczas w naszym szybkomiejskim życiu kulturalnym ktoś w ogóle zechciałby ją dostrzec?"23.

Kamila Sidor, wówczas bileterka Teatru Wybrzeże, powiedziała dla „Super Nowości” o akcji tanich biletów dla bezrobotnych: „Na razie z naszej oferty skorzystało niewielu bezrobotnych, natomiast wiele osób pyta, czy to prawda, że niemal za darmo mogą obejrzeć sztukę"24. Ten cytat pokazuje bardzo ważną kwestię, także dla Szybkiego Teatru Miejskiego. Chodzi o zaakcentowanie i podkreślanie w komunikacji medialnej nowości tego przedsięwzięcia. W tym przypadku widoczna jest bardzo silna tendencja do dyskursywizacji dzieła sztuki. Szybki Teatr Miejski w prasie istnieje jako projekt, w którym wielką rolę odgrywa metatekst. Jacek Sieradzki czyni - zarówno Demirskiemu na poziomie estetycznym, jak i Nowakowi jako organizatorowi odpowiedzialnemu za materialną stronę przedsięwzięcia - zarzut dotyczący nadmiernego blichtru i mówienia w mediach o kulisach tej nowej konwencji ${ }^{25}$. Jeszcze dalej poszła Grażyna Antoniewicz. Krytycznie oceniła estetyczną jakość spektakli. Co ważne, podkreślając, że zarówno w warstwie informacji, jak i sposobu prezentacji Szybki Teatr Miejski jest pusty, zarzuciła jednocześnie, że Demirski i Nowak nie radzą sobie bez uruchomienia kulis ${ }^{26}$.

Istotnie, mówienie o kulisach przedsięwzięcia, łącznie z tym, jakich reportażystów zatrudniono, gdzie prowadzono kwerendy, jak szukano mieszkań

21 H. Jenkins Kultura konwergencji, przeł. M. Bernatowicz, M. Filiciak, Wydawnictwa Akademickie i Profesjonalne, Warszawa 2007.

22 Nowe środki komunikacji, s. 111.

J. Sieradzki Doktrynalny gwizdek miejski.

"Super Nowości", Rzeszów 20.12. 2004 nr 247.

J. Sieradzki, Doktrynalny gwizdek miejski.

G. Antoniewicz Teatralna podróż, „Dziennik Bałtycki. Wieczór Wybrzeża” 17.03. 2004 nr 65. 
na wynajem i jakie ingerencje w umeblowanie poczyniono, i że ekipa teatru w umowie zobowiązuje się do oddania lokalu w stanie pierwotnym itp., było bardzo ważną strategią komunikacyjną. Relacje prasowe z tego projektu właśnie na tym się koncentrują. W wielu pojawia się jeszcze kwestia mody, jaką Demirski zaprowadził w polskich ośrodkach teatralnych. Oznaczałoby to, że nie było to tylko strategią komunikacyjną, ale że była ona skuteczna. Tak autokomentarz przysłonił dzieło sztuki. Dlaczego?

Pierwszą kwestią jest niewątpliwie kategoria nowości. Była to pierwsza akcja w tej konwencji. Co więcej, jeżdżenie autobusem po mieście od spektaklu do spektaklu okazało się bardziej „nowe” aniżeli kwestia konwencji estetycznej oraz sama problematyka. Tak więc większym newsem generującym więcej emocji były w o wiele większym stopniu „kulisy”, dość szeroko autokomentowane niż samo dzieło.

Drugim istotnym elementem tej formy komunikacji jest kwestia relacji między autorem i dziełem. Demirski jawi się tutaj jako prawodawca dyskursu, mówiąc językiem Foucalulta ${ }^{27}$. Jego autorstwo nie polega na kreacji zarówno organizacyjnej, jak i estetycznej projektu, lecz Jego autorstwo rozciąga się na sposób organizacji "kulis" i zespolenia ich w działaniu estetycznym. Nieprzypadkowo fascynacja Teatrem.doc, połączona z doświadczeniami stażu w Wielkiej Brytanii, stała się elementem, który umożliwił przeszczepienie na polski grunt tej konwencji. Autorstwo polega tutaj na kreacji tej konwergentnej konstrukcji komunikacyjnej, a znalazła ona swój wyraz w osobie autora. Problematyczna materialność tego projektu - autobus, który wozi po mieście na kilka różnych spektakli - potrzebowała utekstowienia, nawet w formie autokomentarza.

Metonimia Demirskiego, połączenie wszystkich wątków nie tylko w osobie, ile w autorstwie dramaturga świadczy o szybkości. Jest skrótem całej problematycznej materialności szerokiego projektu. Warto także zauważyć, że podobny sposób kreacji podmiotu autora widoczny jest w stricte literackiej działalności, w samym tekście jego dramatów.

Demirski wpisuje się w nurt nowoczesnej dramaturgii, której jedną z cech charakterystycznych jest to, że artyści budują „siebie jako tekst”. Umieszczają swoją twórczość w sieci autokomentarzy, a rozwój nowoczesnych mediów coraz bardziej im to umożliwia. Z jednej strony artyści tworzą dla siebie tożsamość twórczą, pokazują własne dzieło i próbują dać narzędzia

27 M. Foucault Kim jest autor?, przeł. M.P. Markowski, w: Powiedziane, napisane. Szaleństwo i literatura, przeł. B. Banasiak i in., oprac. T. Komendant, Aletheia, Warszawa 1999. 
do jego interpretacji. Z drugiej zaś wpisują siebie w dzieło sztuki, odwołują się do wydarzeń autobiograficznych, wśród których umieszczają nie tylko fakty z życia osobistego (wspomnienia, status materialny czy pochodzenie - jak w przypadku Demirskiego i Moniki Strzępki), lecz także świadectwa lekturowe.

Znamienne, że powyższe tendencje pojawiają się wtedy, gdy twórcy osiągnęli już sukces, i z tej perspektywy ujawniają siebie i poszukiwania swojej tożsamości. Za pomocą tekstów łączą sztukę ze sobą, scalają ze swoją biografią. Co ważne, są to elementy biografii dotyczące sfery prywatnej, często sytuujące się ponad autokomentarzem i relacją autor - dzieło. Upubliczniane są elementy „wstydliwe” (określenie Tadeusza Kantora) - wśród których znajdują się m.in. wspomnienia rodzinne, doświadczenia emocjonalne, poglądy polityczne czy sytuacja społeczna.

Paweł Demirski w swoich tekstach świadomie pokazuje zlepek tradycji, który ukształtował jego postawę twórczą (swoje pochodzenie, relację prywatną z Moniką Strzępką, diety, poród, kupno mieszkania, swoją karierę itd.; przy jednoczesnym pomieszaniu ikon i cytatów z kultury z językiem popkultury i dyskursem medialnym). Ma to znaczenie zarówno dla konstrukcji nadawcy w tych dramatach, jak i dla świata przedstawionego, który jawi się tutaj jako jednocześnie przez autora wykreowany i zarazem jedynie pokazany. Lektura tych dramatów odbywa się bowiem w konwencji literatury zaangażowanej, zaś polityczność jest tutaj uosabiana przez osobę autora - twórcę polskiego verbatimu, artystę, który sam uosabia konwencję dzieła, zaś komunikuje ją również poza nim.

Politycznie i społecznie zaangażowane teksty koncentrują się na rekonstrukcji dyskursów obecnych we współczesnym obiegu publicznym, zwłaszcza medialnym. Z jednej strony metaliteracki dramat Demirskiego złożony jest $\mathrm{z}$ wielu nadawców, reprezentujących odmienne stanowiska. Jedną z podstawowych strategii komunikacyjnych jest niezajmowanie stanowiska, chwyt uniku autorskiego, dystansowania się od świata przedstawionego. Z drugiej zaś strony autor Niech żyje wojna! wplata teksty dramatyczne w swoją kreację pozaliteracką.

Warto zastanowić się, jakie wyznaczniki tekstowe pokazują odsłanianie się autora w tekście. Nie chodzi bowiem jedynie o proste wykorzystanie elementów autobiograficznych wpisanych w teksty (jak branie kredytu, relacja z porodówki czy metaliterackie odniesienia do krytyków tej konwencji dramatycznej). Interesujące jest, jak obie strategie współdziałają w tekście dramatu i czemu służą. 
Paweł Demirski to dramatopisarz i dramaturg blisko współpracujący ze sceną, z poetyką teatru postdramatycznego. Jego teksty, zgodnie z konwencją czy technologią - posługując się językiem W.B. Worthena ${ }^{28}$ - odbioru dramatu zawierają pewną koncepcję inscenizacyjną. Warto w tym miejscu zaznaczyć, że w utworach tych istnieje minimalna ilość didaskaliów, które ograniczają się do krótkich informacji scenicznych. Jednocześnie praktyka pisarska Demirskiego polega na tym, że wiele elementów tekstu powstaje w czasie prób sytuacyjnych lub jest zapisem dokonanym po tych próbach, literackim przetworzeniem sensów teatralnych. Oczywiście, druk tekstu w formie odrębnego i obszernego tomu (jak w przypadku Parafraz) sugeruje autonomię literatury wobec teatru.

Dramaty Pawła Demirskiego oscylują właśnie pomiędzy niezależnością, samowystarczalnością literacką a intertekstualnością, zależnością od różnego rodzaju tekstów i dotyczącą różnych poziomów utworu. Pomijam zdiagnozowany chwyt „demi-ramy” ${ }^{29}$, oparcie tekstu o pierwowzór literacki (jak Dziady, Wujaszek Wania, Opera za trzy grosze, etc.). Istotniejsze będzie dla mnie osadzenie tych dramatów w ramie świata przedstawionego. Borys Uspienski zaznacza, że dzieło sztuki polega właśnie na istnieniu ramy rozumianej przez analogię do obrazu. Rama jest bowiem elementem, w którym przenika się pozycja zewnętrza i wewnętrzna autora. To moment, kiedy - mówiąc językiem Philippe'a Lejeune'a - „nazwisko na okładce”30 przemyca swój punkt widzenia w kwestie narratora bądź postaci ${ }^{31}$.

Istotą dramatyczności jest postać. Jest to całość zbudowana z różnych motywów - jak podaje Stownik terminów literackich ${ }^{32}$. W dramacie bohater określany jest przez swoje wypowiedzi oraz działania i jest najważniejszym nosicielem idei autora ${ }^{33}$. „Każdy autor angażuje się w swoją twórczość, jednak w przypadku dramatu posiada to wyjątkowe znaczenie, gdyż jego twórca,

W.B. Worthen Dramat: między literaturq a przedstawieniem, przeł. M. Borowski, M. Sugiera, Księgarnia Akademicka, Kraków 2013.

29 J. Krakowska Demi(d)ramy, w: P. Demirski Parafrazy, Wydawnictwo Krytyki Politycznej, Warszawa 2011.

P. Lejeune Wariacje na temat pewnego paktu, przeł. W. Gajewski i in., Universitas, Kraków 2001.

B. Uspienski Poetyka kompozycji, przeł. P. Fast, Śląsk, Katowice 1997. 
poruszając aktualne problemy, wyraża swe poglądy, posługując się wypowiedziami żywych osób na scenie"34 - twierdzi Dorota Tomczuk. Dramat to struktura, w której postaci stanowią o swoich cechach pozwalających wyodrębnić je ze świata przedstawionego. Richard M. Ochmann zaznacza, że nie jest tak, że pisarz tworzy postać, a dopiero potem jej kwestie. Jest odwrotnie, to postaci są tworzone przez akty mowy ${ }^{35}$. To istotne stwierdzenie w odniesieniu do dramatów Demirskiego. Jego bohaterowie określani są jedynie poprzez wypowiadany tekst - nie ma sugestii ich działań, pozycji na scenie itd. Może to być wynikiem silnego powiązania ze spektaklem, jednakże wpływa na specyficzny status bohatera. Bohatera monologizującego, ograniczonego do funkcji wypowiadania tekstu.

Dramatu nie pisze się, lecz go się konstruuje. Wypowiadane w dramacie słowa są wszystkie decyzjami, wypływają z sytuacji i trwają w niej; w żadnym wypadku nie można ich przyjmować jako pochodzących od autora. Dramat należy do autora jedynie jako pewna całość, i ten stosunek przynależności nie wchodzi do samej jego istoty jako dzieła ${ }^{36}$

- twierdzi Peter Szondi. Z kolei Jean-Pierre Sarrazac zauważa kryzys dialogu $\mathrm{w}$ dramacie nowoczesnym (datowanym przez niego od lat 8o. XIX wieku) polegający na monologizacji, na tym, że postaci Czechowa, Ibsena, Hauptmana, Brechta nie wytwarzają akcji ani fabuły w wyniku dialogów ${ }^{37}$.

W nowoczesnym dramacie, według tej terminologii, istnieje „dialog rapsodyczny”, który „łączy i rozłącza” wypowiedzi, kierując uwagę na operatora, podmiot rapsodyczny (jak to definiuje Szondi), rapsoda ${ }^{38}$ - jak go określa Sarrazac, który zarazem pisze o autorze-rapsodzie. Właśnie z tych monologów rekonstruuje się dialog, a głos tego podmiotu często utożsamianego $\mathrm{z}$ autorem jest jedną z wielu wypowiedzi w świecie przedstawionym. Tutaj spełniałaby się polityczność tych dramatów, ich Piscatorowska "gazetowośc".

34 Tamże, s. 15.

35 Richard M. Ochmann Literatura jako akt, przeł. B. Kowalik i W. Krajka, w: Współczesna teoria badań literackich za granicq, t. 4, cz. 1, oprac. H. Markiewicz, Wydawnictwo Literackie, Kraków 1992.

P. Szondi Teoria nowoczesnego dramatu, przeł. E. Misiołek, PIW, Warszawa 1976, s. 13. Akademicka, Kraków 2007. 
Chodzi o to, że momenty autorskiego odkrywania się powodują, że świat przedstawiony jest realny (jakkolwiek przedstawiony niemimetycznie), ponieważ jego częścią jest właśnie osoba autora.

„To jest historia krzyku”, powie Chórzystka w Dziadach. Ekshumacji o dziejach Polski jednocześnie, metatekstowo, wskazując na sposób opowiadania historii, w której sama jest zarówno podmiotem, jak i przedmiotem. Jest to istotne dla dramatów Demirskiego, które są zapisane poprzez specyficzną delimitację tekstu. Dominują tu krótkie wersy, których ukształtowanie przypomina hasła łatwe do wykrzyczenia. Jednocześnie podział tekstu sugeruje zarówno sensy, jak i sposób odczytywania tych fraz. Dodatkowo podkreślone jest to charakterystycznym stosowaniem znaków interpunkcyjnych. Demirski rzadko używa pytajniki (często pytanie obudowane jest metatekstowym fragmentem mówiącym o tym, że postać zadała pytanie, lub kwestią innej postaci, co powoduje interakcję nie tyle dramatyczną, ile jest raczej imitacją działania scenicznego). Składnia oraz intonacja zdaniowa zastępowane są efektami graficznymi - obok wspomnianej już delimitacji, także rozstrzeleniem druku. To powoduje efekt zaniku dialogu dramatycznego.

Zarówno struktura dramatu, jak i jego sensy opierają się na typach postaci. Teksty te złożone są ze stereotypowo utkanych wypowiedzi charakterystycznych dla danej postawy społeczno-politycznej. Właśnie w relacji do postaci najbardziej widoczna jest ingerencja autorska. W Dziadach. Ekshumacji jeden z Weteranów opowiada o przygodzie w księgarni, która skończyła się zatargiem ze sprzedawczynią. Pozornie otrzymujemy zbudowaną ze stereotypów postać kombatanta-emeryta, ubogiego, pragnącego aby jego czyn zbrojny znalazł odbicie w historiografii. Kiedy relacjonujący swoją przygodę bohater zaczyna cytować przekleństwa, jakie miotał pod adresem ekspedientki, pojawia się cytat, legendarne słowa przypisywane Józefowi Piłsudskiemu z przemówienia do rządu Ignacego Daszyńskiego: „Kury szczać prowadzać”39. Posłużenie się cudzą wypowiedzią w dramacie, według Sarrazaca, wprowadza instancję podmiotu cytującego, co z kolei jest jednym z elementów najdobitniej pokazujących tendencję do epizacji tekstu dramatycznego ${ }^{40}$. Jednakże badacz, pisząc o postaci, która wykorzystuje cytat, zaznacza, że taki fragment ma znaczenie dla świata przedstawionego.

Natomiast w dramacie Demirskiego nie pełni on funkcji pomocnej w jego określeniu. Niewiarygodna, stereotypowa postać nie zostanie dookreślona

P. Demirski Dziady. Ekshumacja, w: tegoż Parafrazy, s. 12. 
poprzez odwołanie do Piłsudskiego (nie pomoże w opisaniu charakteru postaci). Tak rozbita narracja postaci służy właśnie „przemyceniu” spojrzenia autorskiego. To bowiem Demirski posługuje się metonimicznym ujęciem wizerunku Józefa Piłsudskiego, zastąpionym czy sprowadzonym w popularnej recepcji, do komicznego (w tym kontekście) bon motu. Żart polega również na ujawnieniu się autora. Jest to bowiem komunikat Demirskiego, który wprowadza metonimicznie pokazanego bohatera, co więcej, bohatera zdolnego do krytyki i niekonwencjonalnych zachowań - w tym przypadku językowych.

Z jednej strony postaci są utkane ze stereotypów, czego same są świadome i co często podkreślają. Na przykład Czechowoski Wojnicki jest ofiarą transformacji po 1989 roku, o czym sam mówi. Jest jednocześnie bohaterem dramatu, kanonu literatury.

«Wujaszek Wania» której bohaterem jestem

jednak głównym

wystawiono jakieś 10000 ooo razy

i każdą zagrano 50 razy -

ciekawe w czyim interesie to było finansowane

to wystawienie?

To jak mam się nie denerwować jak nie trafiłem

500000000 razy - razy - dwa razy?

I nie wiem za czyje pieniądze?

Za czyje pieniądze nie trafiam?

$\mathrm{Z}$ wieczora na wieczór? ${ }^{41}$

Z drugiej zaś strony postaci są zbudowane nie tylko z gestu artysty, lecz są wynikiem autorskiej interpretacji dramatu Czechowa. Ponadto postać jest tutaj nośnikiem idei samego autora dotyczących zarówno oddziaływania autora Mewy na późniejszy dramat, jak i poglądów dotyczących przemian społecznych oraz finansowania kultury w systemie neoliberalnym.

Demirski rozbija podmiotowość swoich bohaterów. Nie tylko poprzez mieszanie swojej perspektywy z wypowiedziami postaci. W Dziadach. Ekshumacji dochodzi do pomieszania wypowiedzi samych bohaterów. W czasie odgrywania II Części kolejne numery zjaw i przyporządkowanie ich Weteranom nie ma znaczenia dla odczytania sensu całej sekwencji - nie

41 P. Demirski Diamenty to węgiel, który wziął się do roboty, w: Parafrazy, 125. 
postaci poprzez swoje wypowiedzi są tutaj jego ośrodkiem. Ma to jedynie znaczenie dla dynamiki, a nie dramaturgii, zarówno tekstu literackiego, jak i układu scenicznego. Kiedy przychodzące duchy wymieniają "strachy" wojenne, mowa jest o partyzantach polskich, którzy popełnili zbrodnię wojenną. Układ tekstu sugeruje, że Weteran 2 byłby postacią reprezentującą postawę gotowości do zakłamywania historii w imię poprawności narracji narodowej. Jednak Demirski rozbija także i tak stereotypowo zaznaczoną podmiotowość.

Weteran 2

Zaraz zaraz zaraz

- Szlag by to trafił czego się doczekałem

w mojej kochanej Polce że mnie ktoś obraża

Weteran 3

że co że by dziecko zastrzelili? [a to ta postać jako Zjawa 13 opowiada tę historię - P.S.]

Weteran 1

może i zastrzelili

Weteran 2

ale to pewnie przez pomyłkę - broń się czyści. ${ }^{42}$

Przyporządkowanie poszczególnych kwestii do postaci nie pozwala na charakterystykę bohaterów. Postaci służą tutaj jedynie do przekazywania treści, prezentacji kolejnych postaw, czy problemów, jakie autor dostrzega we współczesnym dyskursie na temat wojny i jej estetyzacji, czego ewidentnym przykładem jest aluzja intertekstualna do Kartoteki Tadeusza Różewicza.

Autor Demirskiego wchodzi do świata przedstawionego również jako prawodawca dyskursu. Kiedy Weteran 1 z Dziadów. Ekshumacji opowiada o książce, którą chciał kupić, powie, że:

pachniała farbą drukarską tak jak czasami pachniała podłoga w domu mojej matki służącej kiedy ją napastowałem..$^{43}$ 
Delimitacyjno-składniowa gra językowa powoduje zamierzoną wieloznaczność, która ma tu charakter komiczny. Jednakże wieloznaczność ta nie odsyła jedynie do sposobów odczytywania tego fragmentu, lecz dotyczy także nadawcy tego komunikatu. Z jednej strony odnosi się do mitu „ziemiańskiego", znów mamy pozorną charakterystykę stereotypowo pokazanej „przedwojny". Jednocześnie mit ten jest złamany. Demirski uruchamia zarazem mit "przedwojennego oficera”, jednocześnie konfrontując go z żołnierzem-proletariuszem. Zarazem jest to krytyka mitu feudalnego, a zwłaszcza recepcji mitu feudalnego w II RP. Posłużyłem się Foucaultowską transdyskursywnością, ponieważ takie odczytanie możliwe jest właśnie poprzez utożsamienie „rapsoda" z autorem. Dzięki temu możliwe jest uwzględnienie kontekstu innych utworów Demirskiego. Zarówno literackich (jak np. Wimię Jakuba S.), jak też autokomentarzy dotyczących własnej twórczości, jak też deklarowanej w wypowiedziach pozaliterackich lewicowości, a więc realności światopoglądowej autora. Kreowana podmiotowość postaci złamana jest tu osobą autora, który odsłania się poprzez konstrukcję językową.

Dramaty Pawła Demirskiego oprócz swoich funkcji użytkowych dla sceny są przeznaczone do lektury. Autor wykorzystuje chwyty graficzne (przede wszystkim delimitację i interpunkcję) do zwiększania wieloznaczności. Jednakże jest ona możliwa w kodzie graficznym, w obcowaniu z książką. Kiedy duchy przychodzą na dziady, w wersji Demirskiego następuje pomieszanie. Autor wykorzystuje do tego graficzne możliwości tekstu literackiego.

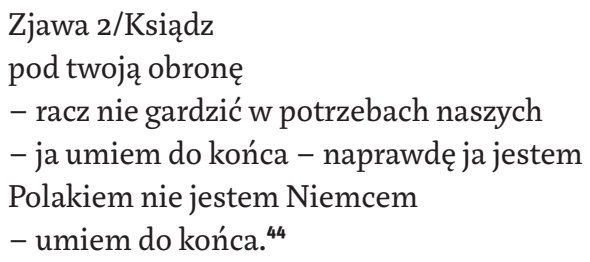

Wieloznaczność granicząca z chaosem semantycznym jest potrzebna Demirskiemu do stworzenia atmosfery wyliczeń okropieństw wojennych. W całej sekwencji bowiem mieszają się zbrodnie wojenne, zbrodnie w swojej ogólności zbliżające się do kategorii zbrodni wojennej. Jednakże cechuje je wszystkie duża frenetyczność. Głos autorski ujawnia się tutaj właśnie poprzez nagromadzenie, przywołanie, stereotypowe zacytowanie różnorodnych 
dyskursów dotyczących przeszłości. Ewidentnie, są to postawy zaczerpnięte ze współczesności znanej autorowi. Demirski, rozbijając kilkanaście dyskursów na cztery postaci, automatycznie wyklucza możliwość charakterystyki bohaterów poprzez wypowiadany tekst i działania. Przekreśla także próbę identyfikacji bohatera z wypowiadanym tekstem. Głos autorski objawia się w tendencyjnym dobraniu dyskursów, oraz prowokacyjnym ich pomieszaniu - czemu dziwią się nawet same postaci. Subiektywizacja, tendencyjność, co jednocześnie oznacza autorskość układu, powoduje konfrontację z widzem ${ }^{45}$.

Wspomniany już Borys Uspienski zaznacza, że zwrot do widza jest wyrazem potrzeby artysty, aby utrwalić „percepującego odbiorcę, czyli konieczność istnienia pewnego abstrakcyjnego podmiotu, z punktu widzenia którego opisywane wydarzenia zyskują określone znaczenie (stają się bytami znakowymi)"46. Jednakże podmiotem prowokacji, jej nadawcą jest tutaj bezpośrednio autor. To on konfrontuje się z czytelnikami, ponieważ on kreuje się jako ten, który przypomina, szuka nowego odbiorcy - „normalnych ludzi” jak mówił organizując Szybki Teatr Miejski. W tym miejscu kreacja pozatekstowa ma znaczenie dla świata przedstawionego. $Z$ jednej strony dramat staje się aktualny, a odbiór i kontrowersje to jedynie potwierdzają. Z drugiej zaś tekst przestaje realizować funkcję autora, staje się raczej komunikatem osobistym. Wpisuje się to w typowo nowoczesną tendencję do objawiania i skrywania się podmiotu w literaturze, zauważoną przez Ryszarda Nycza, do „fikcjonalizacji i empiryzacji głosu autorskiego"47.

To uwiarygodnianie w przypadku Demirskiego owocuje konsekwentnie prowadzoną formą dramaturgiczną. Estetyka krytyczna w przypadku zapisu literackiego przejawia się w sugerowaniu formy dramatycznej, imitacji, czy cytacie struktury ${ }^{48}$ dramatu. Przykładem może być fragment z Dziadów. Ekshumacji, kiedy zacytowana zostaje piosenka Południca. Wprowadzony utwór nie jest poprzedzony żadnym sygnałem tekstowym, nie przynależy też do żadnego z bohaterów. Jest ewidentnie autorskim wtrętem. Co więcej, nie tylko gestem pisarza, lecz osobistą odpowiedzią, asocjacją uruchomioną wspominaniem sielskiej polskiej wsi. Jednakże do tego tekstu, „ludowszczyzny”

45 E. Bal Cielesność w dramacie, Księgarnia Akademicka, Kraków 2007. 
odwołują się postaci dramatu. Widać więc tu tendencję do utrzymywania i przekraczania formy dramatycznej. Epizacja polega jednak na „monologowej ramie"49 - jak to określił Michaił Bachtin - samego autora.

Pisanie przypomina dziś ofiarę złożoną z życia albo też dobrowolne zniknięcie Ja, którego nie trzeba przedstawiać w książkach, gdyż spełnia się ono w egzystencji autora. Dziełu, które powinno zapewnić autorowi nieśmiertelność, przypadła rola jego zabójcy"50

- napisał Michael Foucault.Pojawia się więc paradoks, polegający na tym, że w takim ujęciu, komentarz jest osobny od dzieła. Jednocześnie pochodzące z różnych poziomów interteksty byłyby nie tylko kluczem, sposobem objaśniania teatru, lecz przede wszystkim kreowaniem języka mówienia o twórczości teatralnej. Co więcej, odbiorca tego typu dzieła dostaje sygnały, że klucz interpretacyjny, zwerbalizowanie dyskursu, z którego wyrasta utwór, leży poza nim.

Sugerowanie relacji intertekstualnych ma charakter perswazji. Nie tyle bowiem tłumaczy poszczególne rozwiązania artystyczne, ile wytwarza pewną tożsamość. Dochodzi więc do uaktualnienia nie tylko dwóch tekstów - ale przede wszystkim uaktualniona jest współczesna recepcja prototekstu (jego znaczenia, funkcji w kulturze i roli w tradycji teatralnej). Uaktualniony zostaje nie tylko on, lecz głównie sposób myślenia o teatrze.

Mamy do czynienia z sytuacją przekroczenia dzieła sztuki w tym sensie, że wymaga ona od odbiorcy znajomości języka, w którym artysta się wypowiada. Jednocześnie ten język jest stwarzany i autodefiniowany w komentarzu. Co więcej, sytuacja komunikacyjna powoduje, że przedmiotem kreacji jest tu przede wszystkim połączenie biografii twórcy z dziełem.

W serialu Artyści występuje autoparodia Demirskiego, pisarz Paweł. Autor Dziadów. Ekshumacji oddziałując na widza zarówno samym dziełem, jak i kreacją swojej osoby pokazuje, że do widza skierowany jest hipertekstualny komunikat złożony zarówno z dramatu, jak i z autokomentarza i samej postawy autora wykreowanej przez działalność pozaartystyczną (a komunikowaną w mediach). Wspomniałem o scenariuszu Artystów, ponieważ została w nim zawarta strategia kreacji autora w tekście, właściwa dla całej twórczości

49 M. Bachtin Problemy poetyki Dostojewskiego, przeł. W. Grajewski, w: /a - Inny. Wokół Bachtina, red. D. Ulicka, t. 1, Universitas, Kraków 2009, s. 164. 
Demirskiego. Do widza skierowany jest tekst, którym jest sam artysta. Autoparodia w serialu pokazuje, że konstrukcja siebie jako tekstu znajduje również wymiar ikoniczny. Tak jak performatywny projekt Szybkiego Teatru Miejskiego potrzebował tekstualizacji, tak tutaj ośrodkiem znaczenia staje się wizerunek twórcy. Z tych samych powodów Monika Strzępka wprowadza swoją bluzę jako znak ikoniczny we Wimię Jakuba S. Hipertekst generowany przez ogrywanie kulis dzieła zostaje tutaj sprowadzony do tekstu, jakim jest sama postać artysty.

\section{Abstract}

\section{Paweł Stangret}

CARDINAL STEFAN WYSZYŃSKI UNIVERSITY (WARSAW)

The Author and the Backstage: The Case of Paweł Demirski

Stangret examines the dramatic work of Paweł Demirski by juxtaposing his strictly literary output with the work he did on the project Szybki Teatr Miejski [The Fast City Theatre]. The main problem is the creation of the authorial subject within specifically artistic communication. Treated hypertextually, the literary work, which is linked to autocommentary and the uncovering of the author's perspective, causes the author himself to become the text in which the above-mentioned elements come together. Stangret sheds light on the communication strategies of this particular kind of text. The main means of communicating "oneself as a text" is the intimation of transgressing the speaking element for the sake of immediate expression. The artist creates himself as an author writing a text whose meaning is largely based on action beyond the work. Another element is the strategy of provocation whose main factor is the speed of transmission. Stangret shows the ways in which the poetics of Demirski's plays can be inscribed in modern media communication.

\section{Keywords}

Paweł Demirski, contemporary drama, dramaturgy, dramaturge, political theatre 